\title{
PENGARUH KEPEMIMPINAN, PENGEMBANGAN KARIR DAN KOMPENSASI TERHADAP KINERJA KARYAWAN PT. BANK COMMONWEALTH JAKARTA
}

\author{
Valentines Jen dan Kurniati W. Andani \\ Program Studi Manajemen Fakultas Ekonomi Universitas Tarumanagara, Jakarta \\ valentinesjennn@gmail.com
}

\begin{abstract}
The purpose of this study was to examine the effect of leadership, career development and compensation on employee performance at PT. Bank Commonwealth Jakarta. The sample used was taken by purposive sampling with 115 respondents and data analysis using SmartPLS. The result of this study indicate that all three leadership, career development, and compensation had significant effects on employee performance.
\end{abstract}

Keywors: Leadership, Career Development, Compensation, Employee Performance.

Abstrak: Tujuan penelitian ini adalah untuk mengetahui pengaruh kepemimpinan, pengembangan karir dan kompensasi terhadap kinerja karyawan PT. Bank Commonwealth Jakarta. Sampel yang digunakan diambil dengan purposive sampling dengan 115 responden dan analisis data menggunakan SmartPLS. Hasil penelitian ini menunjukkan bahwa ketiga kepemimpinan, pengembangan karir dan kompensasi berpengaruh signifikan terhadap kinerja karyawan.

Kata Kunci: Kepemimpinan, Pengembangan Karir, Kompensasi, Kinerja Karyawan.

\section{LATAR BELAKANG}

PT. Bank Commonwealth ("Commonwealth Bank") adalah anak perusahaan dari Commonwealth Bank of Australia (CBA) yang berbasis di Sydney, yang merupakan institusi keuangan publik terbesar di Australia yang terdaftar pada Australia Securities Exchange (ASX).

Commonwealth Bank fokus pada segmen Retail Banking dan Usaha Kecil Menengah (UKM), menyediakan berbagai produk dan layanan perbankan - serta menjadi penyedia layanan Wealth Management - dengan menawarkan solusi keuangan yang disesuaikan untuk melayani kebutuhan pelanggan.Sumber energi manusia dalam sesuatu industri ialah penentu yang sangat berarti untuk keefektifan berjalannya aktivitas di dalam industri. Keberhasilan dari kinerja seorang dalam sesuatu bidang pekerjaan banyak ditetapkan oleh tingkatan pengembangan karir, style kepemimpinan serta pemberian kompensasi terhadap bidang pekerjaan yang dijalankannya.

Beberapa cara yang dapat dilakukan oleh perusahaan untuk menciptakan kinerja yang baik dan meningkatkan kinerja karyawan adalah dengan memperhatikan pengembangan karir yang diberikan untuk dapat mengeksplor kemampuan yang dimiliki karyawan. Kemudian gaya kepemimpinan yang dilakukan dapat menciptakan suasana kerja yang nyaman dan memberikan kompensasi kepada setiap karyawan sesuai dengan ketentuan yang berlaku. Namun pada prakteknya, manager HRD Commonwealth Head Office kantor World Trace Center 5 mengatakan karyawan yang memiliki kinerja memuaskan hanya berkisar 80\% karyawan bank sedangkan sisanya masih kurang memuaskan dan perlu ditingkatkan lagi agar semua tujuan dalam perusahaan dapat tercapai. (Sumber: Wawancara dengan Pak Robby 
selaku manager HRD PT Bank Commonwealth. Kemudian dapat dilihat dari grafik penilaian kinerja bank Commonwealth kantor pusat di Jakarta:

Tabel 1. Penilaian Kinerja Karyawan

Bank Commonwealth Kantor World Trace Center

\begin{tabular}{|l|l|l|l|l|}
\hline \multirow{2}{*}{$\begin{array}{l}\text { Penilaian } \\
\text { Kinerja }\end{array}$} & \multicolumn{2}{|l|}{ Tahun 2018 } & \multicolumn{2}{l|}{ Tahun 2019 } \\
\cline { 2 - 5 } & Orang & Persentase & $\begin{array}{l}\text { Jumlah } \\
\text { Orang }\end{array}$ & Persentase \\
\hline Baik & 50 & $39.70 \%$ & 42 & $31 \%$ \\
\hline Cukup & 44 & $34.60 \%$ & 40 & $29.90 \%$ \\
\hline Kurang & 33 & $25.90 \%$ & 51 & $40 \%$ \\
\hline Total & 127 & 100,00 & 127 & 100,00 \\
\hline
\end{tabular}

Berdasarkan uraian di atas, peneliti tertarik untuk mempelajari tiga faktor tersebut di atas, yaitu pengembangan karir, gaya kepemimpinan dan gaji. Oleh karena itu, penelitian ini bertujuan untuk menganalisis bagaimana faktor-faktor yang diuraikan dalam mempengaruhi peningkatan kinerja karyawan.

\section{KAJIAN TEORI}

\section{Kepemimpinan}

Dalam suatu organisasi, faktor kepemimpinan memegang peranan yang penting karena pimpinan itulah yang akan menggerakkan dan mengarahkan perusahaan dalam mencapai tujuan. Meskipun seorang pemimpin tidak mudah dalam menjalankan tugasnya karena harus memahami setiap perilaku bawahan yang berbeda-beda. Seorang pemimpin harus mengetahui betul fungsi pemimpin dan sekaligus mengetahui unsur-unsur kepemimpinan sebagai aktivitas mempengaruhi, kemampuan mengajak, mengarahkan, menciptakan dan mencetuskan ide.

Adapun beberapa pendapat yang dikemukakan oleh para ahli tentang kepemimpinan, diantaranya menurut Robbins dan Judge (dalam Teguh Sriwidadi dan Oey Charlie, 2011) menyebutkan bahwa kepemimpinan merupakan kemampuan untuk mempengaruhi suatu kelompok guna mencapai sebuah visi atau serangkaian tujuan yang direncanakan. Kemudian menurut Rivai dan Mulyadi (dalam Teguh Sriwidadi dan Oey Charlie, 2011) kepemimpinan adalah proses mengarahkan dan mempengaruhi aktivitas-aktivitas yang ada hubungannya dengan pekerjaan para anggota kelompok.

Menurut John Pfiffner dalam buku seputar pengetahuan (2015) berpendapat kepemimpinan adalah kemampuan mengkoordinasikan dan memotivasi orang-orang dan kelompok untuk mencapai tujuan yang di kehendaki. Sedangkan menurut F. I. Munson dalam "The Management of Man" kepemimpinan sebagai kesanggupan atau kemampuan untuk mengatasi orang-orang yang sedemikian rupa agar mencapai hasil yang sebesar-besarnya dengan kemungkinan pergesekan yang sekecil-kecilnya dan sebesar mungkin terjalinnya kerja sama.

\section{Pengembangan Karir}

Pengembangan karier (career development) adalah suatu kondisi yang menunjukkan adanya peningkatan status seseorang dalam suatu organisasi pada jalur karir yang telah ditetapkan dalam organisasi.

Menurut Noeewll (1998), pengembangan karier merupakan tugas organisasi untuk membentuk hubungan dengan orang yang mengelola kariernya, karena karier tersusun dari pergantian antara individu dan organisasi. Individu merencanakan karier mereka guna 
meningkatkan status dan gaji mereka, memastikan keselamatan pekerjaan dan mempertahankan kemampuan pasaran mereka dalam pasar tenaga kerja yang berubah.

Dalam jangka lebih panjang, perkembangan diri perlu dikaitkan dengan rencana karier seseorang, tergantung ke arah mana seseorang ingin berkembang, menurut Skala waktu yang ditentukan sendiri. Nawawi (2001), menyatakan beberapa pengertian pengembangan karier yaitu:

1. Pengembangan karier adalah suatu rangkaian (urutan) posisi atau jabatan yang ditempati seseorang selama masa kehidupan tertentu. Pengertian ini menempatkan posisi atau jabatan seseorang pekerja dilingkungan suatu organisasi perusahaan, sebagai bagian rangkaian dan posisi atau jabatan yang ditempatinya selama masa kehidupannya posisi atau jabatan itu ditempatinya selama kehidupan sebagai pekerja, sejak awal memasuki suatu organisasi atau perusahaan, sampai saat berhenti.

2. Pengembangan karier adalah perubahan nilai-nilai sikap dan motivasi yang terjadi pada seseorang, karena dengan penambahan atau peningkatan usianya menjadi semakin matang.

3. Pengertian karier adalah usaha yang dilakukan secara formal dan berkelanjutan dengan difokuskan pada peningkatan dan penambahan kemampuan seorang pekerja. Dari ketiga pengertian pengembangan karier tersebut di atas, terlihat bahwa pengertian pertama dan kedua mengakui karier yang bersifat individual, merupakan bagian dari ketentuan nasib seseorang sebagai manusia.

\section{Kompensasi}

Kompensasi sering kali disebut sebagai bentuk penghargaan yang diberikan kepada karyawan sebagai balas jasa atas kontribusi yang mereka berikan kepada perusahaan. Handoko (2014) mengemukakan tentang kompensasi adalah sesuatu yang diterima para karyawan sebagai balas jasa untuk kerja mereka, dengan tujuan untuk meningkatkan prestasi kerja, motivasi, dan kepuasan kerja karyawan.

Menurut Hasibuan (2012) kompensasi adalah semua pendapatan yang berbentuk uang, barang langsung atau tidak langsung yang diterima karyawan sebagai imbalan atas jasa yang diberikan kepada perusahaan. Husein Umar (2010) menyatakan bahwa kompensasi adalah: adalah segala sesuatu yang diterima oleh karyawan berupa gaji, upah, insentif, bonus, premi, pengobatan, asuransi dan lain-lain yang sejenis yang di bayar langsung perusahaan. Kemudian Darsono (2011) bahwa kompensasi merupakan segala sesuatu bentuk imbalan yang diterima seseorang (pekerja) sebagai imbalan atas kerja mereka.

Berdasarkan pendapat diatas dapat simpulkan bahwa kompensasi merupakan suatu imbalan yang diberikan pada karyawan sebagai bentuk balas jasa yang meliputi kompensasi finansial dan non finansial serta berbagai tunjangan yang diberikan bagi para karyawan.

Menurut Mondy (2008), bentuk dari kompensasi yang diberikan perusahaan kepada karyawan terdapat dimensi kompensasi yang dikelompokkan menjadi 2 (dua) bagian, yaitu:

1. Financial compensation (kompensasi finansial).

Kompensasi finansial artinya kompensasi yang diwujudkan dengan sejumlah uang kartal kepada karyawan yang bersangkutan.

2. Non-financial compensation (kompensasi non finansial).

Kompensasi non-finansial adalah balas jasa yang diberikan perusahaan kepada karyawan bukan berbentuk uang, tapi berwujud fasilitas. 


\section{Kinerja Karyawan}

Menurut Mangkunegaran (2012) kinerja adalah hasil kerja secara kualitas dan kuantitas yang dicapai oleh seseorang karyawan dalam melaksanakan tugasnya sesuai dengan tanggung jawab yang telah diberikan kepada karyawan.

Lebih lanjut Mangkunegaran (2012) menyatakan bahwa pada umumnya kinerja dibedakan menjadi dua, yaitu kinerja individu dan kinerja organisasi. Kinerja individu adalah hasil kerja karyawan baik dari segi kualitas maupun kuantitas berdasarkan standar kerja yang telah ditentukan, sedangkan kinerja organisasi adalah gabungan dari kinerja individu dengan kinerja kelompok. Kemudian kinerja merupakan suatu konsep yang multi dimensional mencakup tiga aspek yaitu sikap (attitude), kemampuan (ability) dan prestasi (accomplishment) (Rivai Veithzal \& Basri dalam Harsuko, 2011).

Menurut Wirawan (2009) Kinerja adalah keluaran yang dihasilkan oleh fungsi-fungsi atau indikator-indikator suatu pekerjaan atau suatu profesi dalam waktu tertentu yang diukur melalui hasil kerja, perilaku kerja, dan sifat pribadi yang berhubungan dengan pekerjaan. Wirawan (2009) menjelaskan dimensi kinerja yaitu:

1. Hasil Kerja.

Hasil kerja adalah hal yang dihasilkan dari apa yang telah dikerjakan (keluaran hasil atau keluaran jasa), dapat berupa barang dan jasa yang dihitung dan diukur kuantitas dan kualitasnya. Kualitas kerja yang merupakan kemampuan karyawan menunjukkan kualitas hasil kerja yang ditinjau dari segi ketelitian dan kerapihan. Kuantitas kerja yang merupakan kemampuan karyawan dalam menyelesaikan sejumlah hasil tugas pada setiap harinya.

2. Perilaku kerja.

Dalam kesehariannya di tempat kerja, seorang karyawan akan menghasilkan dua bentuk perilaku kerja, yaitu perilaku pribadi ialah adalah perilaku yang tidak ada hubungannya dengan pekerjaan, contohnya cara berjalan, cara berbicara, cara makan siang, dll. Sedangkan perilaku kerja adalah perilaku karyawan yang berhubungan dengan pekerjaannya.

3. Sifat pribadi.

Sifat pribadi adalah sifat yang dimiliki oleh setiap karyawan. Sifat pribadi karyawan yang diperlukan dalam melaksanakan pekerjaannya. Sebagai seorang manusia biasa, seorang karyawan memiliki banyak sekali sifat bawaan, artinya sifat yang memang sudah dibawa sejak lahir atau watak. Sifat bawaan yang diperoleh sejak lahir ini akan diperkuat oleh pengalaman-pengalaman yang diperoleh pada saat manusia beranjak dewasa.

\section{Kerangka Pemikiran}

Kerangka penelitian dapat digambarkan sebagai berikut:

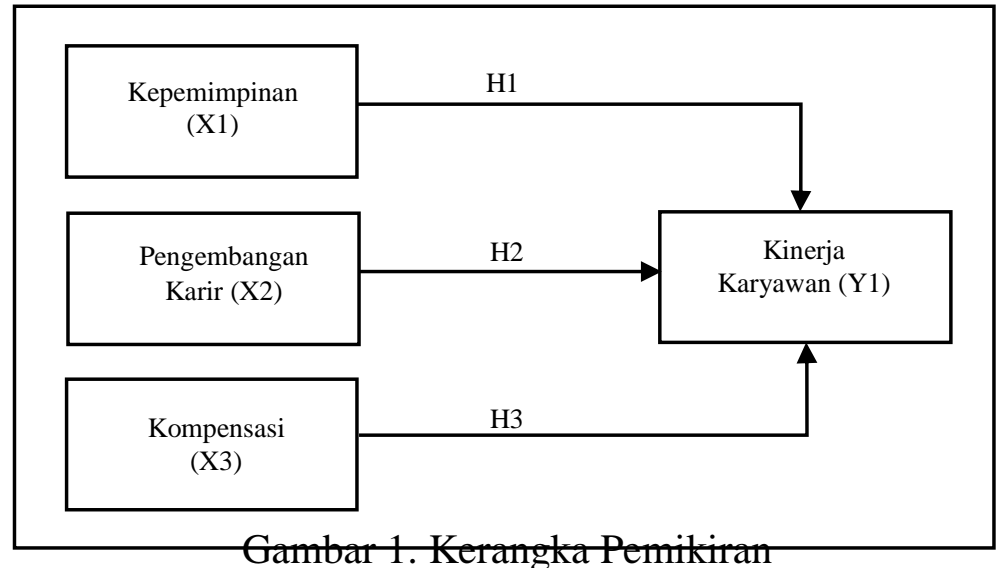


Hipotesis 1:

H0 : Pengembangan Karir tidak berpengaruh secara positif terhadap peningkatan kinerja karyawan.

Ha : Pengembangan Karir berpengaruh secara positif terhadap peningkatan kinerja karyawan. Hipotesis 2:

H0 : Kepemimpinan tidak berpengaruh secara positif terhadap peningkatan kinerja karyawan. Ha : Kepemimpinan berpengaruh secara positif terhadap peningkatan kinerja karyawan. Hipotesis 3:

H0 : Kompensasi tidak berpengaruh secara positif terhadap peningkatan kinerja karyawan.

Ha : Kompensasi berpengaruh secara positif terhadap peningkatan kinerja karyawan.

\section{METODOLOGI}

Variabel terikat dalam penelitian ini adalah kinerja karyawan sedangkan variabel bebas nya adalah kepemimpinan, pengembangan karir, dan kompensasi. Metode pegambilan sampel yang digunakan dalam penelitian ini adalah purposive sampling.

Populasi yang terdapat dalam penelitian ini adalah karyawan yang sudah mengikuti pelatihan dan pegembangan karir Banking Staff Program. Karyawan yang sudah mengikuti pelatihan dan pengembangan karir sebanyak 115 orang. Pada bagian Back Office, karyawan baru dan karyawan yang sudah bekerja $<3$ tahun di Bank Commonwealth. Pada bagian karyawan sumber daya manusia, kriteria yang memenuhi persyaratan adalah karyawan yang sudah mengikuti pelatihan dan pengembangan karir dan telah bekerja $>3$ tahun. Berdasarkan kriteria-kriteria yang sudah terpenuhi diatas, maka jumlah sampel dalam penelitian ini sebanyak 115 sampel.

\section{HASIL ANALISIS DATA}

\section{Deskripsi Subjek Penelitian}

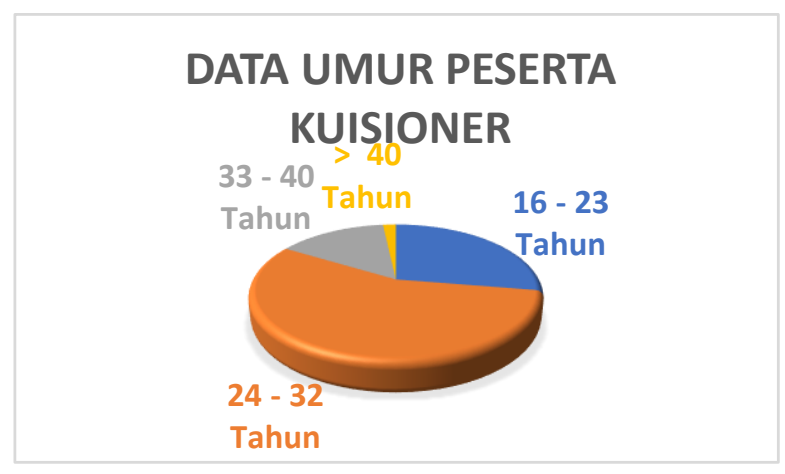

Gambar 2. Data Umur Peserta Kuisioner

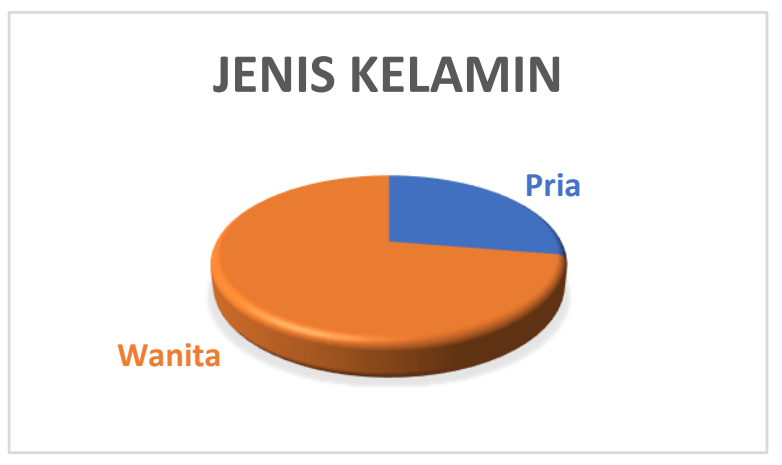


Gambar 3. Jenis Kelamin

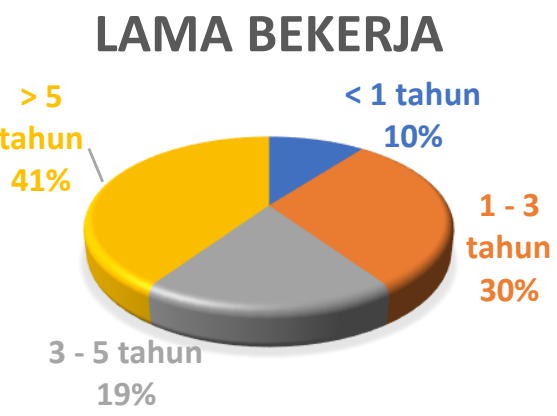

Gambar 4. Lama Bekerja

\section{Uji Validitas}

Tabel 2. Uji Validitas

\begin{tabular}{|l|l|l|l|l|}
\hline \multicolumn{1}{|l|}{} & X1 & X2 & X3 & Y1 \\
\hline GK1 & 0.772 & & & \\
\hline GK2 & 0.793 & & & \\
\hline GK3 & 0.768 & & & \\
\hline GK4 & 0.823 & & & \\
\hline KK1 & & & & 0.864 \\
\hline KK2 & & & & 0.879 \\
\hline KK3 & & & & 0.862 \\
\hline KP1 & & & 0.813 & \\
\hline KP2 & & & 0.882 & \\
\hline KP3 & & & 0.891 & \\
\hline KP4 & & & 0.861 & \\
\hline PK1 & & 0.735 & & \\
\hline PK2 & & 0.748 & & \\
\hline PK3 & & 0.818 & & \\
\hline PK4 & & 0.825 & & \\
\hline
\end{tabular}

\section{Uji Reliabilitas}

Tabel 3. Uji Reliabilitas

\begin{tabular}{|l|l|l|l|l|}
\hline & Cronbach's Alpha & rho_A & $\begin{array}{l}\text { Composite } \\
\text { Reliability }\end{array}$ & $\begin{array}{l}\text { Average Variance Extracted } \\
\text { (AVE) }\end{array}$ \\
\hline X1 & 0.799 & 0.804 & 0.869 & 0.623 \\
\hline X2 & 0.789 & 0.803 & 0.863 & 0.612 \\
\hline X3 & 0.885 & 0.888 & 0.921 & 0.744 \\
\hline Y1 & 0.837 & 0.839 & 0.902 & 0.754 \\
\hline
\end{tabular}

\section{Uji Hipotesis}


Tabel 4. Uji Hipotesis

\begin{tabular}{|l|l|l|l|}
\hline Hipotesis & Hubungan Variabel & T-Statistics & Kesimpulan \\
\hline $\mathrm{H} 1$ & $\mathrm{GK} \Rightarrow \mathrm{KK}$ & 3,809 & Hipotesis Diterima \\
\hline $\mathrm{H} 2$ & $\mathrm{PK} \Rightarrow \mathrm{KK}$ & 3,949 & Hipotesis Diterima \\
\hline $\mathrm{H} 3$ & $\mathrm{KP} \Rightarrow \mathrm{KK}$ & 4,141 & Hipotesis Diterima \\
\hline
\end{tabular}

\section{DISKUSI}

Dalam penelitian ini dapat dilihat bahwa karakteristik responden menurut jenis kelamin karyawan PT. Bank Commonwealth di Jakarta yang terlibat dalam penelitian ini sebanyak 88 responden (72\%) dengan jenis kelamin perempuan. Hal ini menunjukkan bahwa karyawan PT. Bank Commonwealth di Jakarta didominasi dengan pekerja perempuan yang memiliki kecenderungan untuk lebih teliti dan ulet dalam bekerja.

Dalam penelitian ini dapat dilihat bahwa karakteristik reponden menurut usia karyawan PT. Bank Commonwelth di Jakarta yang terlihat dalam penelitian ini sebanyak 56 responden (65\%) berusia 24 - 32 tahun. Hal ini menunjukkan bahwa karyawan PT. Bank Commonwealth di Jakarta didominasi oleh pekerja usia produktif 24 - 32 tahun yang dianggap sudah memiliki pengalaman kerja dan semangat kerja tinggi, juga menghasilkan kinerja yang baik.

Dalam penelitian ini dapat ilihat bahwa karakteristik responden menurut lama bekerja karyawan PT. Bank Commonwealth di Jakarta yang terlibat dalam penelitian ini sebanyak 47 responden $(41 \%)$ dengan jangka waktu 5 tahun atau lebih. Hal ini menunjukkan bahwa karyawan PT. Bank Commonwealth di Jakarta didominasi oleh pekerja yang setia dan pastinya memiliki kinerja yang baik.

Berdasarkan uji validitas bahwa masing-masing item pernyataan dari setiap variabel dalam penelitian ini memiliki factor loadings $\geq 0,6$. Hal ini menunjukkan bahwa semua item pernyataan dinyatakan layak atau valid untuk digunakan dalam penelitian ini.

Berdasarkan uji reliabilitas dengan menggunakan Cronbach Alpha, nilai dari Cronbach Alpha pada setiap variabel adalah $\geq 0,6$. Hal ini menunjukkan bahwa semua variabel yang digunakan dalam penelitian ini larayk atau reliabel untuk digunakan dalam penelitian serupa.

\section{PENUTUP}

Berdasarkan hasil analisis data dan uji hipotesis dalam penelitian ini, dapat disimpulkan bahwa (1) Kompensasi yang diterima karyawan Bank Commonwealth Jakarta berpengaruh secara positif terhadap peningkatan kinerja karyawan, (2) Pelatihan yang diberikan Bank Commonwealth Jakarta berpengaruh secara positif terhadap peningkatan kinerja karyawan, (3) Gaya kepemimpinan di Bank Commonwealth Jakarta berpengaruh secara positif terhadap peningkatan kinerja karyawan, (4) Pelatihan, gaya kepemimpinan dan kompensasi berpengaruh secara positif terhadap peningkatan kinerja karyawan.

Berdasarkan hasil penelitian secara keseluruhan dan kesimpulan diperoleh, dapat dikembangkan beberapa saran. Adapun saran-saran yang dikemukakan adalah (1) Diharapkan perusahaan memerhatikan apa yang menjadi kebutuhan dan keinginan para karyawan dalam hal menjunjung pencapaian hasil kinerja yang baik. Bagi pekerja, pekerja diharapkan untuk berkomitmen menjalankan peraturan dan sanksi yang ada, (2) Bagi peneliti selanjutnya, dapat melakukan penelitian lebih lanjut, apakah terdapat faktor lain yang mampu juga mempengaruhi kinerja karyawan atau juga dengan menggunakan variabel lain sebagai mediasi. 


\section{DAFTAR PUSTAKA}

Dessler, Gery. "A Framework for Human Resource Management", New Jersey: Pearson Education Inc, 2011.

Cheng, J. Lang, "Examining The Implementation of Six Sigma Training and its Relationship with Job Satisfaction and Employee Morale", Vol. 113, Hal. 100-110. Asian Journal on Quality, 2012.

Choudhury, Dibyendu dan Mishra, Sasmita,"Compensation-Satisfaction Correlation at Workplace: A Study on BPO at Orissa", International Journal of Business and Management Tomorrow, Vol. 1, No. 1.

Daft, Richard L.. "Era Baru Manajemen”, Terj. Edisi kesembilan buku II bekerja sama dengan Tita Maria Kanita, Salemba. Jakarta, 2011.

Dessler, Gery. "Human Resource Management", New Jersey : Pearson Education Inc, 2011.

Fahmi, Irham. "Manajemen Kepemimpinan”, Edisi Kedua, Alfabeta. Bandung, 2013.

Hasibuan, Malayu SP. "Manajemen Sumber Daya Manusia”, Edisi Revisi, PT. Bumi Aksara. Jakarta, 2012.

Handoko. "Manajemen Personalia dan Sumber Daya Manusia," Penerbit Salemba Empat. Jakarta, 2014.

Idrus, Muhammad. "Metodologi Penelitian ilmu Sosial Pendekatan Kualitatif dan Kuantitatif", Penerbit Erlangga. Jakarta, 2012.

Mangkunegara, A Prabu. "Manajemen Sumber Daya Manusia Perusahaan", PT. Remaja Rosdakarya. Bandung, 2012.

Mathis, Robert L. dan Jackson, John H. " Human Resource Management”, Tomson Learning Academic Resource Center. United States of America, 2008.

Mathis, Robert L. dan Jackson, John H. "Human Resource Management : Essential Prespectives", Cengage Learning. United States of America, 2011.

Marwansyah. "Manajemen Sumber Daya Manusia" Edisi Kedua, Alfabeta. Bandung, 2010.

Mujiono, Imam. "Kepemimpinan dan Keorganisasian”, UII Press. Yogyakarta, 2002.

Meldona. "Manajemen Sumber Daya Manusia:Prespekif Integratif", UIN-Malang Press. Malang, 2009.

Mustofa, Kamil. "Model Pendidikan dan Pelatihan (Konsep dan Aplikasi)", Alfabeta. Bandung, 2006

Moeheriono. "Pengukuran Kinerja Berbasi Kompetensi", Kharisma Putra Utama Offset. Jakarta, 2012.

Mondy." Manajemen Sumber Daya Manusia”, Erlangga. Jakarta: 2008

Moeheriono, Prof. Dr. M.Si. "Pengukuran Kinerja Berbasis Kompetensi",cetakan ke 2, BPFE. Yogyakarta, 2010.

Nawawi, Hadari. "Manajemen Sumber Daya Manusia Untuk Bisnis Yang Kompetitif”, Gadjah Mada University Press. Yogyakarta, 2003.

Sedarmayanti. "Manajemen Sumber Daya Manusia Reformasi Birokrasi dan Manjemen Pegawai Negeri Sipil”, PT. Refika Aditama. Bandung: 2010.

Sekaran, Uma. "Research Methode For Business: Metodologi Penelitian Untuk bisnis". Salemba Empat. Jakarta, 2006.

Simamora, Henry. "Manajemen Sumber Daya Manusia", Edisi III, STIE YKPN. Yogyakarta, 2004.

Sugiyono.“Metode Penelitian Bisnis”, CV Alfabeta, Bandung, 2009.

Sugiyono. Metode Penelitian Kuantitatif, kualitatif dan R \& D. Alfabeta, Bandung. 2015.

Sulistyo, Joko. “6 Hari Jago SPSS 17”, Cakrawala, Yogyakarta, 2012.

Suliyanto. "Ekonometrika Terapan: Teori \& Aplikasi dengan SPSS", Andi, Yogyakarta, 2011.

Sukirno, Sadono "Pengantar Bisnis”, Kencana Prenada Media Grop. Jakarta, 2013. 
Sutrisno, Edy. "Manajemen Sumber Daya Manusia”, Prenada Media Group. Jakarta, 2011. Thoha, Miftha, "Kepemipinan dalam Manajemen”, Raja GrafindoPersada, Jakarta, 2010.

Umar, Husein. "Desain Penelitian MSDM dan Perilaku Karyawan”, PT.Raja Grafindo Persada. Jakarta, 2010.

Veithzal, Rivai. "Manajemen Sumber Daya Manusia untuk Perusahaan dari Teori ke Praktik", PT. Raja Grafindo Persada. Jakarta, 2009.

Veithzal, Rivai dan Mulyadi, Deddy. "Kepemimpinan dan Perilaku Organisasi”, Edisi ketiga dan cetakan ke 8, Kharisma Putra Utama Offset. Jakarta, 2011. Wibowo. " Manajemen Kinerja”, Kharisma Putra Utama Offset. Jakarta, 2012.

Wirawan. Evaluasi Kinerja Sumber Daya Manusia: Teori Aplikasi dan Penelitian. Salemba Empat, Jakarta. 2009. 